Island Studies Journal, Vol. 5, No. 2, 2010, pp. 237-250

\title{
Mariculture and Marine Spatial Planning: Integrating Local Ecological Knowledge at Kaledupa Island, Indonesia
}

Brian W. Szuster

Department of Geography

University of Hawai 'i at Mānoa

Honolulu HI, USA

szuster@hawaii.edu

and

Hatim Albasri

Research Center for Indonesian Aquaculture

Indonesian Ministry of Marine Affairs and Fisheries

Jakarta, Indonesia

hatim@cria.indosat.net.id

\begin{abstract}
Economic development on Indonesia's numerous small islands faces a number of challenges stemming from the islands' isolation and resource limitations. Mariculture has been promoted as a viable development strategy in these areas, and this research assesses a marine spatial planning approach to support net-cage grouper mariculture development in waters surrounding Kaledupa Island located southeast of Sulawesi. Data collection focused on 15 biophysical capability parameters, plus an additional 7 suitability parameters assessed through interviews with villagers and local experts. Capability analysis identified 4,511 hectares capable of sustaining grouper mariculture within the 8,582 hectares study area. Suitability analysis identified 2,667 suitable hectares based on villager opinions and 4,083 suitable hectares based on local expert opinions. Reliance on villager opinions and resolution of fragmentation issues reduced the final area deemed suitable to 2,423 hectares. This study highlights the importance of utilizing local ecological knowledge in marine spatial planning, and emphasizes the need for follow-up studies, monitoring and enforcement of environmental regulations to ensure that negative impacts do not emerge in island communities as a result of mariculture development.
\end{abstract}

Keywords: Kaledupa, Indonesia, islands, mariculture, marine spatial planning, local ecological knowledge

C 2010: Institute of Island Studies, University of Prince Edward Island, Canada.

\section{Introduction}

Small islands possess a long history as a research focus within a diverse range of fields such as geography, anthropology, ecology, evolutionary biology and sociology (Baldacchino, 2006). The manageable size of small islands allows these areas to act as ideal field laboratories (Jackson, 2004) and natural resource management researchers in particular have gravitated toward these sites to investigate sustainability issues stemming 


\section{B. W. Szuster \& H. Albasri}

from their fragility, resource limitations and economic development challenges (Kokkranikal et al., 2003). Small island development is particularly important in Indonesia where artisanal fisheries continue to represent a primary economic activity on many of this archipelagic nation's 17,000 islands. Aquaculture has been identified as a viable development alternative to artisanal fisheries in Indonesia (Nurdjana, 2006) and grouper farming in particular has been promoted because extensive nearshore areas could potentially support this form of mariculture. It is estimated that Indonesia has 812,000 hectares of potential grouper mariculture sites, but only 8,000 hectares of this total are effectively used at present (ibid.). Grouper has also emerged as a focus for mariculture development because it is one of the most valuable market fishes in Indonesia. It is favoured by existing fish farmers as a result of strong market demand (Rimmer et al., 2004; Yamamoto, 2006), and in large cities such as Hong Kong where groupers are traded as live fish, prices can range from US\$8/kg for gold spot grouper (Ephinephelus coioides) to $\$ 95$ or more for mouse grouper (Cromileptes altivelis) (Williams et al., 2006).

Given the large and growing demand for sustainable economic development opportunities in many of Indonesia's small island communities, planning tools are needed that can achieve both income generation and the protection of coastal resources (Pet-Suede, 2003: 138). Marine spatial planning is one such tool and this study investigates an application focusing on grouper mariculture development in areas offshore of Kaledupa Island located southeast of Sulawesi. The study area includes four main islands: Wanci, Kaledupa, Tomia and Binongko (Figure 1); but Kaledupa was selected as the study site because it is protected by long fringing reefs that create substantial nearshore areas potentially suitable for mariculture. It is also home to ten coastal villages where a majority of residents are artisanal fishers who are in need of economic development opportunities that do not negatively affect existing fisheries, seagrass or coral reef resources. The waters surrounding Kaledupa Island are also within the 1.39 million hectare Wakatobi Marine National Park, and are considered a local use zone in the park zoning system which restricts use to residents of the surrounding islands. Indonesia possesses large areas that could potentially support additional mariculture production of commercial species; but marine spatial planning tools are urgently needed to support both the need for income generation and the maintenance of environmental quality on small islands such as Keladupa (Pet-Suede, 2003).

Marine spatial planning is, however, inherently multidisciplinary and relies on the integration of biophysical, socio-economic and cultural information to be successful. Mariculture research focusing on husbandry and biophysical capability aspects of marine spatial planning are plentiful, but studies on social and cultural topics such as local ecological knowledge (Williams \& Baines, 1993; Aswani and Hamilton, 2004) continue to be under-valued or overlooked (Kile et al., 2000). A variety of explanations have been proposed to explain this situation. A majority of marine resource managers are trained in the biophysical sciences and often do not possess experience with social science techniques such as interviewing or surveying that are required to interpret local ecological knowledge (Hamilton \& Walter, 1999). Elitism and/or ethnocentrism have also been cited as reasons for overlooking the value of this type of information (Johannes, 1982). The insufficient integration of local ecological knowledge has been particularly pronounced in mariculture planning (Walters, 2007) which is a serious flaw given the explosive growth of sea farming 
in many coastal regions. The proper siting of facilities has been demonstrated to be one of the most important factors in an effective marine spatial planning system that supports sustainable mariculture development (Ross et al., 1993). This aspect of marine spatial planning typically consists of two primary elements: site capability analysis which evaluates the biophysical capacity of an area to support production, and site suitability which considers additional socio-economic factors (FAO, 1989). It is within this latter phase that social and cultural factors play a particularly important role, and this study investigates the influence of expert and local ecological knowledge on net cage grouper site suitability analysis carried out in marine areas off Kaledupa Island, Indonesia.

\section{Methods}

Marine spatial planning activities that focus on assessing the initial potential for mariculture development typically include two main elements: site capability analysis and site suitability analyses. Approaches to site capability analysis are diverse and can be integrated with considerations of site suitability, but typically include all biophysical parameters and mitigating factors affecting a site's ability to support a proposed use (Cross \& Kingzett, 1992). Biophysical characteristics such as water quality, water quantity, bathymetry, climate, predator and micro and macro fauna are commonly applied (Kapetsky \& Manjarrez, 2007) and most capability classifications provide three classes: capable, moderately capable, and not capable (Karthik et al., 2005; Perez et al., 2003; McLeod et al., 2002). However, examples exist that use more than three classes (Salam et al., 2005; Rajitha et al., 2007) or only two distinctive capability classifications (Nath et al., 2000). Site suitability is often used interchangeably with site capability (FAO, 1989) but it is important to differentiate between these terms. Site suitability focuses on extrinsic aspects of resource use such as potential conflicts, land use patterns, market conditions, infrastructure and technical support (Nath et al., 2000). These are in addition to the biophysical parameters that represent to focus of site capability analysis. Approaches that utilize geographic information systems (GIS) are common with a simple overlay process representing the most common technique. In this approach all areas deemed capable of supporting a proposed resource use are evaluated with suitability factors weighted equally within and across categories. Weighted overlay techniques can also be used and assume that each factor possesses a different degree of importance based on prior research or the subjective input of analysts or decision makers (Rajitha et al., 2007).

\section{Data Collection and Analysis}

Data collection within the Kaledupa Island study area was conducted during the month of August 2007 with both biophysical and socioeconomic parameters collected during this time period. The research area is relatively homogenous with respect to physical, chemical and geographic conditions as there are no large rivers or streams on Kaledupa Island. Biophysical measurements were taken between 10:00 AM and 2:00 PM at 31 sampling stations along the coastline of the study area where water depth ranged between 5 and 100 meters. This water depth is a strict requirement for net pen aquaculture and sites not meeting this requirement were excluded from sampling. The position of each station in areas possessing adequate water depth was selected using a grid superimposed on a base map of the study area. Sampling stations were centered within individual grid squares 
approximately $1 \mathrm{~km}^{2}$ in area and plotted using a field GARMIN GPS MAP Sounder 178. Nath et al. (2000) and others emphasize that biophysical parameters should be measured over time to obtain accurate data and reflect seasonal changes. Time and equipment restrictions limited this study to a single survey which took place in the early rainy season and represents a worst case scenario with respect to environmental parameters such as sediment, salinity, nitrate, phosphate and $\mathrm{pH}$ due to high precipitation and sediment runoff (Caffrey et al., 2007; Interlandi \& Crockett, 2003; Smith \& Kreutzberger, 1987). Time series data collection is clearly the preferred option for site capability evaluation as this approach can effectively identify random or predictable sources of environmental change. Single sampling periods representing worst case scenarios can also produce useful information (Nath et al., 2000: 255-256); and site capability evaluations utilizing this approach may be considered valid if the identified variability of environmental parameters does not compromise the viability of mariculture operations (Cross \& Kingzett, 1992). Even though a single point data collection strategy conducted during a sub-optimal period such as the rainy season can be used to assess site capability, these results should be confirmed by subsequent time series analysis to verify long-term environmental conditions or investigate atypical results produced by unusual weather conditions.

Biophysical parameters specific to grouper were based on studies by Kapetsky \& Manjarrez (2007), Buitrago et al. (2005), Nath et al. (2000), Chou \& Lee (1997), Ross et al. (1993), FAO (1989) and Caine et al. (1987). Grouper possess a range of biophysical preferences (water temperature, dissolved oxygen, salinity, ammonia-nitrogen concentration, nitrate concentration and turbidity) that have been documented by previous research (Table 1). Chou and Lee (1997) also suggest that water depth should be at least five metres so that floating net-cages possess at least three metres clearance from the bottom. A maximum water depth of 50 metres is recommended, although 100 metres is suggested by various researches. Wave height is suggested to be less than 1 metre and tidal velocity is between $10 \mathrm{~cm} / \mathrm{s}$ and $100 \mathrm{~cm} / \mathrm{s}$ to avoid straining the net-cages and distorting cage shape (ibid.).

Successful grouper mariculture not only depends on the biophysical capability of the environment to support cultured fish, but also the consideration of a wide range of socioeconomic and resource use factors (Kapetsky \& Manjarrez, 2007; Perez et al., 2005) which are also included in Table 1. Net cages should be positioned away from local fishing grounds, shipping lanes, harbors and tourist sites (Henderson \& Davies, 2000) and the existence of conservation zones, spawning grounds and critical habitats such as coral or sea grass must also be considered (Walters, 2007; Vilalba, 2006; Kryvi, 1995). A rapid rural appraisal approach was used to conduct semi-structured interviews based on the approach adopted by Kapetsky \& Manjarrez (2007), Perez et al. (2005), and Nath et al. (2000). A purposive sample of adult villagers was selected on the basis of occupation and gender. The sample included 25 men and 5 women, with the youngest interviewee being 23 years and the oldest 71 years of age. (The mean age was 40.) Most interviewees worked as fishers and seaweed farmers with only a small number employed as farmers or skilled laborers. Three interviews were conducted in each of Kaledupa's ten villages for a total of 30 in this phase of the research. Semi-structured interviews were also conducted with an "expert" sample that included six resource management professionals from the Wakatobi National Park Authority and a local university researcher. All individuals defined as 
experts had extensive knowledge of fisheries and environmental conditions in the study area as a result of conducting multiple scientific studies in the region.

Table 1: Capability and Suitability Parameters.

\begin{tabular}{|c|c|c|c|}
\hline \multicolumn{4}{|c|}{ SITE CAPABILITY } \\
\hline Parameters & Optimal Capability & Method & Source \\
\hline Bathymetry & $>5 \mathrm{~m}-<100 \mathrm{~m}$ & Field survey & Chou \& Lee (1997) \\
\hline $\mathrm{pH}$ & $7.0-8.5$ & Field survey & FAO (1989) \\
\hline Temperature & $26-31{ }^{0} \mathrm{C}$ & Field survey & Chou \& Lee (1997) \\
\hline Dissolved Oxygen & $>3 \mathrm{ppm}$ & Field survey & Chou \& Lee (1997) \\
\hline Salinity & $15-33 \mathrm{ppt}$ & Field survey & Chou \& Lee (1997) \\
\hline Nitrate & $<4 \mathrm{mg} /$ liter & Field survey/ lab analysis & Chou \& Lee (1997) \\
\hline Phosphate & $<70 \mathrm{mg} / \mathrm{liter}$ & Field survey/ lab analysis & Chou \& Lee (1997) \\
\hline $\begin{array}{l}\text { Wave Height } \\
\text { Water Current }\end{array}$ & $\begin{array}{l}<1 \mathrm{~m}^{-1} \\
>10 \mathrm{~cm} \mathrm{~s}^{-1}-<100 \mathrm{~cm} \mathrm{~s}^{-1}\end{array}$ & $\begin{array}{l}\text { Field survey } \\
\text { Field survey }\end{array}$ & $\begin{array}{l}\text { Chou \& Lee (1997) } \\
\text { Chou \& Lee (1997) }\end{array}$ \\
\hline Sediment & Rock, sand or gravel & Field survey & Caine et al. (1987) \\
\hline Water Clarity & Secchi depth $>3 \mathrm{~m}$ & Field survey & Buitrago et al. (2005) \\
\hline Red Tide & No red tide reported & Interviews and literature & Buitrago et al. (2005) \\
\hline Parasites + Disease & No parasite reported & Interviews and literature & Buitrago et al. (2005) \\
\hline Pollution & No pollution reported & Interviews and literature & Buitrago et al. (2005) \\
\hline Tidal (Low tide) & $>2 \mathrm{~m}$ & Literature & Tookwinas (1989) \\
\hline \multicolumn{4}{|c|}{ SITE SUITABILITY } \\
\hline Parameters & Optimal Suitability & Method & Source \\
\hline Coastal activities & No overlap & Surveys and interviews & $\begin{array}{c}\text { Kapetsky \& } \\
\text { Manjarrez (2007), } \\
\text { Perez et al. (2005) }\end{array}$ \\
\hline Transportation & No overlap & Surveys and interviews & $\begin{array}{c}\text { Kapetsky \& } \\
\text { Manjarrez (2007), } \\
\text { Perez et al. (2005) }\end{array}$ \\
\hline Diving sites & Buffer & Surveys and interviews & Perez et al. (2005) \\
\hline Fishing grounds & No overlap & Interviews & Perez et al. (2005) \\
\hline Harbours & $>500 \mathrm{~m},<8 \mathrm{~km}$ & Surveys and interviews & Perez et al. (2005) \\
\hline Protected areas & $>1000 \mathrm{~m}$ & Surveys and interviews & Kyrvi (1995) \\
\hline Benthic species & No overlap & Surveys and interviews & Vilalba (2006) \\
\hline Spawning ground & $>1000 \mathrm{~m}$ & Interviews & Kyrvi (1995) \\
\hline
\end{tabular}


Both local villagers and experts were asked to pinpoint physical features such as fishing or spawning grounds on a base map, and a substantial amount of supplementary data was also gathered from local fishers on issues such as fishing patterns, target species, boat and gear types, and fishing seasons. Interview participants were asked to pinpoint important physical features or resource use areas on a base map, and were repeatedly asked for clarifications and for more detailed information. Features identified by interviewees were cross-checked by field visits to ensure the accuracy of this information. The resulting maps were then scanned and geo-referenced to fit a previously constructed digital base map, and each suitability parameter was digitized to determine spatial coordinates, import attribute information, and produce eight separate suitability layers. A 200 meters buffer area was also created around each island to limit interpolation analysis because of visible nearshore turbidity.

GIS interpolation analysis was performed using ArcGIS 9.1 and Kriging techniques (Bolstad, 2005) to display the distribution of values for each capability and suitability parameter in the study area on a 1999 Indonesian base map. The second component of Kriging interpolation was used because it can predict spatial correlations between two locations based on their distance and similar behaviour. After the interpolation process, different layers generated from the capability and suitability variables were overlaid on the base map using Boolean operators used in the spatial selection of features (ibid.). This approach produces only two categories in the classification, but creates a clear definition of suitability without any lack of clarity between these distinct categories (Nath et al., 2000). The use of GIS facilitates the manipulation of complex environmental data and is particularly valuable in marine site selection because it can show strong interactions among capability parameters in areas that are relatively homogenous and lacking obvious boundaries (Kapetsky \& Manjarrez, 2007). Results of the GIS interpolation analysis were finally overlaid to produce two suitability maps based on: (1) local ecological knowledge of villagers, and (2) expert knowledge of the study area.

\section{Results and Discussion}

\section{Capability Analysis}

Site capability analysis was performed using fifteen parameters identified in Table 1 . The study area generally possesses a gravel-sand substrate that is well suited to grouper farming with bathymetry profiles dominated by a large number of lagoons with water depth ranging from 5 metres to 53.9 metres. Wave height is typically less than 1 metre because of protection by islands and long barrier reefs, and surface water currents range from $3 \mathrm{~cm} / \mathrm{s}-56 \mathrm{~cm} / \mathrm{s}$ with the average current speed of $26.38 \mathrm{~cm} / \mathrm{s}$. Water currents are acceptable, although slower than suggested optimal values in certain areas such as lagoons and near barrier reefs. Water temperature measurements were very uniform and within the optimal range for grouper, ranging between $26.8^{\circ} \mathrm{C}$ to $29^{\circ} \mathrm{C}$. Water clarity was well above the minimum standards, but turbidity levels were sub-optimal because of unusually strong winds and currents during the sampling period. Previous research has identified relatively constant turbidity levels far below 10 nephelometric turbidity units (NTU) during both wet and dry seasons in the study area (BTNKW, 2003; COREMAP, 2001). Turbidity 
parameters were still included in the overall capability framework proposed by this study, but utilization of data from the single field data collection period in August 2007 was limited since these do not appear to be representative of long-term conditions. A 200 meters buffer was, however, created around each island in the study site to limit analysis in areas potentially affected by nearshore turbidity. Sampled $\mathrm{pH}$ values ranged from 6.49 7.68 with seven stations located in the southern part of the study area near traditional seaweed farms possessing values below suggested optimal values. Dissolved oxygen (DO) at all sampling stations was very good (ranging between $3.54-6.16 \mathrm{ppm}$ ) with an average level of $4.8 \mathrm{ppm}$. Nitrate concentrations in stations located away from the coastline are also optimal for grouper ranging from $1.6 \mathrm{mg} / \mathrm{L}-3.9 \mathrm{mg} / \mathrm{L}$. Three sampling stations near the coastline were above threshold concentrations and this could also be related to data collection during rainy season which can produce elevated nitrate concentration through nitrogen fixation. Phosphate levels were within the optimal range from $0.567-9.353 \mathrm{mg} / \mathrm{L}$. Red tide, parasites, fish diseases and pollution were not found in the study area: this information is based on interviews with villagers, local experts, and fish farmers who have engaged in fish fattening in the area for a considerable period of time.

This biophysical capability data was analyzed and imported into the GIS with each parameter mapped in a single layer and interpolated to show distributions across the entire study area using Kriging interpolation. The interpolation process was then further assessed using a Boolean classification which produced a binary classification (Nath et al., 2000) with each layer possessing only two potential outcomes (capable or not capable). The final result of this stage was a composite capability map with a single thematic layer defining 4,511 hectares of water area possessing the biophysical conditions to support grouper netcage mariculture out of the entire 8,582 hectare study area (Figure 1). A complex seabed profile was the primary reason for the discontinuous pattern displayed on this map, but shallow lagoons, sand bars and reef barriers also dominate the southern portion of the study area and reduce water flows to sub-optimal levels. Slow water currents cannot remove excess organic inputs (such as food and faeces) and parameters such as oxygen or other physical or chemical water qualities can be affected by low or stagnant water flows. In contrast, northern portions of the study area possess fewer lagoons, sand bars or reef barriers that can affect water quality parameters, and capability parameters are well within the recommended range for grouper production. A number of small isolated areas were excluded from subsequent suitability analysis to reduce fragmentation and concentrate farms into larger areas which facilitates future monitoring and impact assessment studies.

\section{Suitability Analysis}

Site suitability analysis was performed using the eight parameters including: protected areas, fishing, spawning and seagrass areas, benthic species, transportations routes, harbours, and dive sites and other coastal activities (Table 1). Both villagers and experts identified suitability parameters on a base map during interviews, and the location of shipping lanes was crosschecked during field research and plotted with a handheld GPS. The resulting maps were then scanned and geo-referenced to fit the previously constructed digital base map. Locations of each suitability parameter were then digitized to determine spatial coordinates, import attribute information, and produce eight suitability layers. 
Figure 1: Site Capability Map for Grouper Mariculture

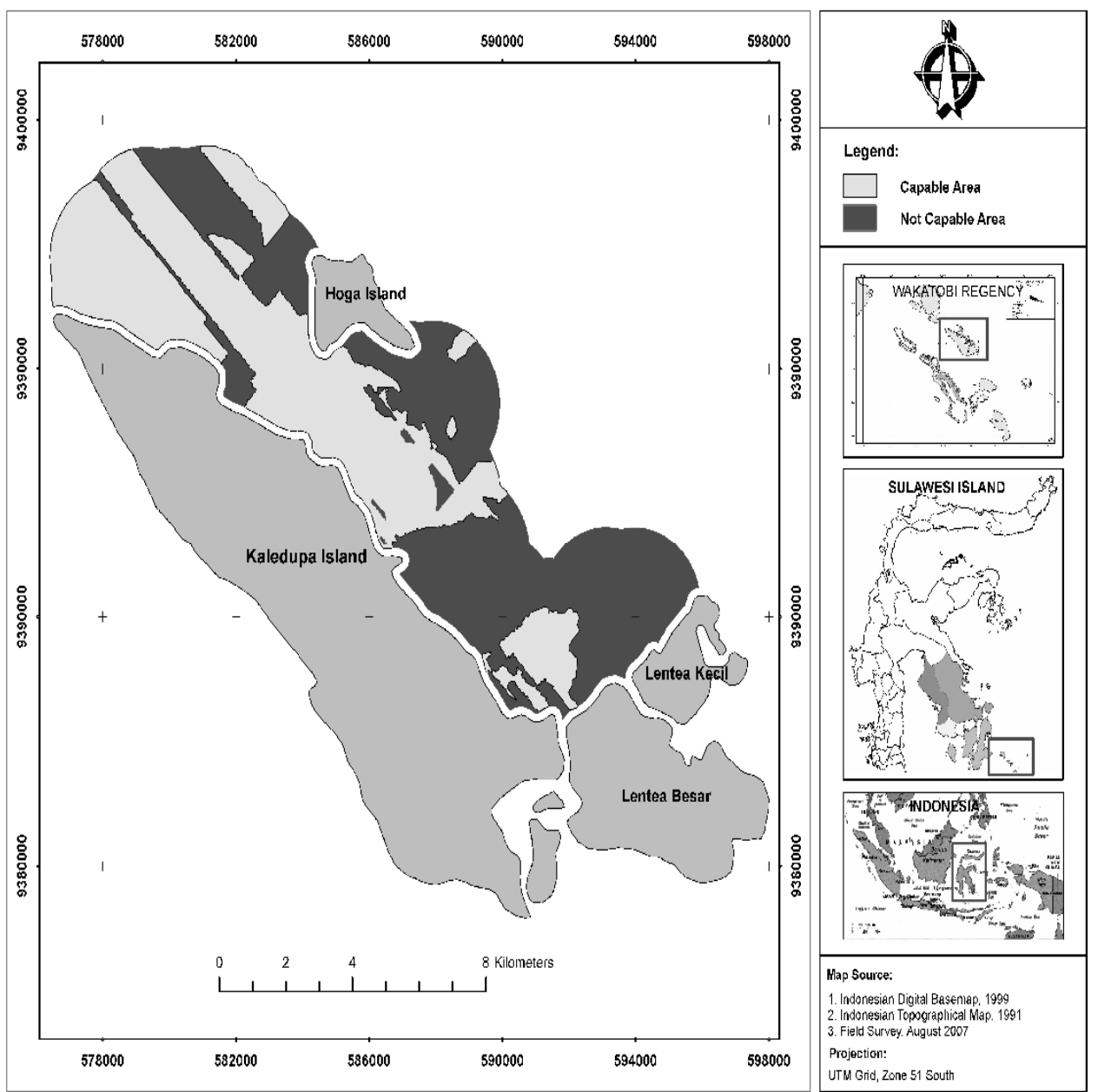

The waters surrounding Hoga Island support some of the most significant coral and fish population in Wakatobi National Park and this area also provides spawning grounds for several grouper species and green turtle nesting habitats. Areas surrounding Hoga were, therefore, excluded from consideration as farm sites even though these areas are highly capable of supporting grouper production. Buffer analysis was performed on shipping lanes, protected areas, dive spots, tourist sites and harbour layers by applying a specific buffer distance to each parameter based on previous grouper suitability research (Kapetsky \& Manjarrez, 2007; Perez et al., 2005). Seaweed farming and seagrass collection did not 
require buffer analysis because these activities only required that net-cages do not overlap with existing locations.

The results of the suitability analysis were then overlaid to produce two separate maps based on villager and expert knowledge of the study area. A villagers' site suitability map identified a total of 2,667 hectares as "suitable" for grouper farming from the 4,511 hectares previously defined as "capable" of supporting this activity. Most of the suitable sites are located in the central and northern portions of the study area as villagers identified large areas containing seaweed farms and protected areas as unsuitable for grouper farming. Other parameters - such as seagrass, dive spots, and harbours excluded smaller areas, and shipping lanes - also contributed to a degree of fragmentation in the villager suitability map. Suitability analysis based on the expert interviews resulted in an area of 4,083 hectares being classified as "suitable" for grouper farming from a total of 4,511 hectares previously classified as "capable". Although both expert and villager groups identified certain well known marine protected areas and dive sites as unsuitable for mariculture, the general lack of distinction between capability and suitability by the expert group highlights their more limited knowledge of coastal environments as compared to villagers who interact with local resources and activities on a daily basis. The expert group was unaware of many seagrass areas and considered most seaweed farming sites to be suitable for mariculture. In contrast, villagers were far more aware of specific ecologically important seagrass areas and did not consider seaweed culture sites to be suitable for grouper mariculture unless existing seaweed farmers decided to convert their farm sites to this activity. The substantial discrepancy in suitability evaluations between experts and villagers in this study illustrates that local ecological knowledge is a powerful supplement to site suitability analysis which must not be overlooked. Local residents involved in coastal livelihoods such as fishing are often very knowledgeable about specific activities and local site conditions which can influence site suitability evaluations. Of course local ecological knowledge cannot be successfully applied without maintaining rigorous standards of data collection and analysis, and researchers should avoid a sentimental belief local people "know best" without attempting to understand why and under what circumstances (Richards, 1980: 185).

On the basis of the capability analysis, field observations, and detailed information provided both by local villagers and experts, a final suitability map was prepared using villager information as the primary input to the assessment of grouper mariculture suitability in the study area. Fragmentation was reduced by removing several small isolated areas to concentrate mariculture operations in larger blocks, and this would have the added benefit of simplifying future monitoring of the mariculture activities. Several areas currently used for seaweed farming are also suitable for grouper and could be converted to grouper production if market prices for seaweed are low. This would require permission of the seaweed farmers, but could potentially add an additional 705 hectares to the overall area classified as suitable for grouper mariculture. After reducing fragmentation and adding areas capable of grouper production but currently allocated to seaweed farming, a final suitability map largely based on villager preferences identified approximately 2,423 hectares of Kaledupa Island coastal waters as suitable for grouper net-cage mariculture (Figure 2). 
Figure 2: Final Site Suitability Map for Grouper Mariculture

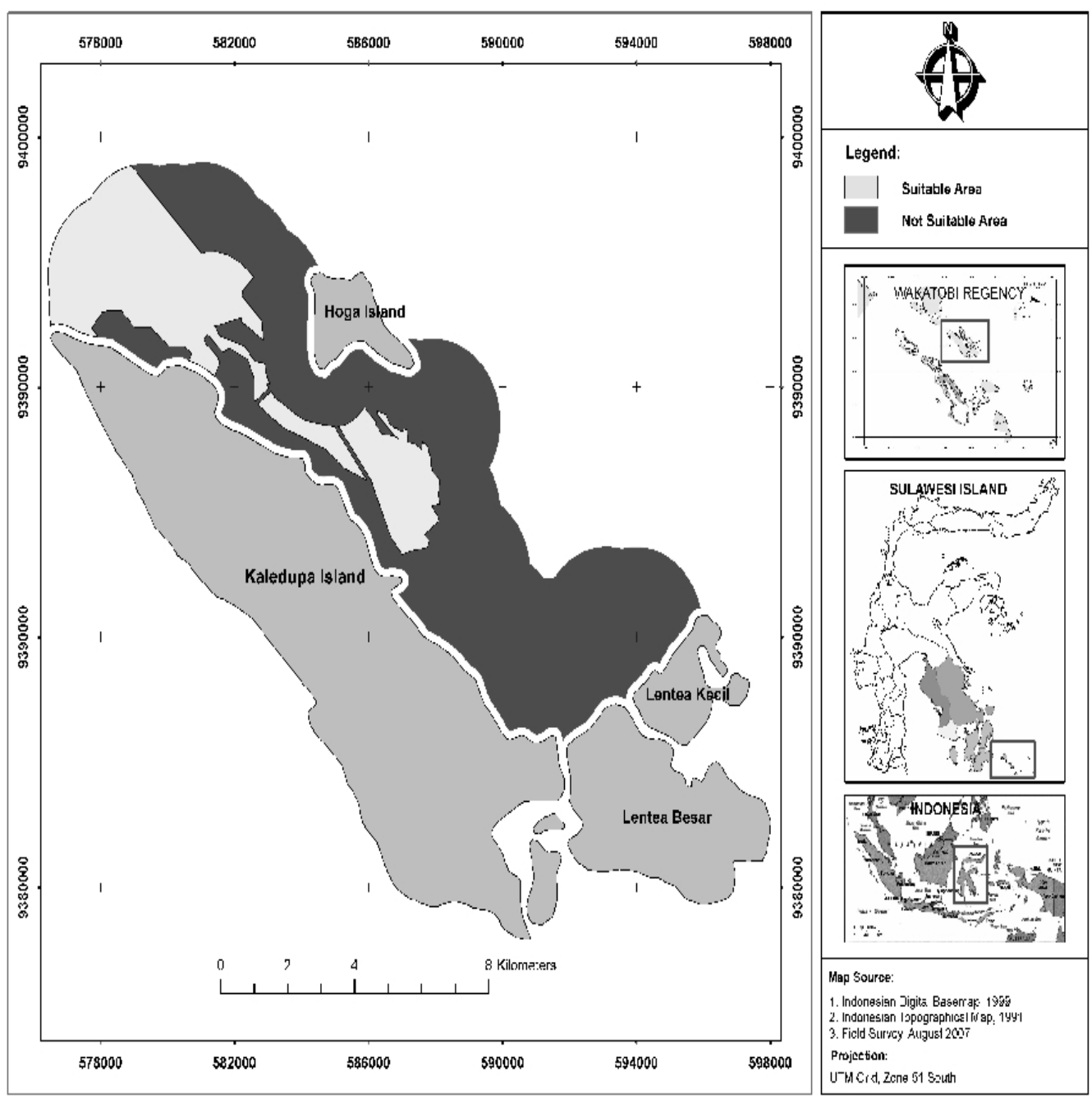

\section{Conclusions}

Marine spatial planning is growing in importance as a field of study, and specific planning tools such as GIS-assisted site suitability analysis can play a very useful role in assessing the potential implications of mariculture development on small islands such as Kaledupa. This study highlights the increasing realization that local ecological knowledge can play a significant role in site suitability analyses. Local ecological knowledge can supplement or even improve upon more typical government information sources, but it can also offer important opportunities for group discussions, problem solving and conflict resolution at the community level. Information on environments and activities gleaned from expert groups is certainly useful in conducting mariculture site suitability analysis. These data 
sources can supply technical or scientific perspectives that local villagers may not be aware of or unable to provide. But expert information sources should not be applied exclusively or automatically considered superior to local ecological knowledge. Expert data sources should be supported by local information provided by island residents who are often much more familiar with local resources, activities and conditions. Local and expert perspectives are not mutually exclusive, but complementary, and the inclusion of both sources of information is required to ensure a comprehensive approach to mariculture site suitability analysis on island communities.

The findings of this study also suggest that areas such as Wakatobi National Park can potentially support both conservation and sustainable livelihood activities important to the island communities. Achieving these often contradictory goals is, however, heavily reliant upon both local and government support of marine spatial planning activities such as site suitability analysis to avoid conflict and meet clear conservation objectives. Many marine conservation areas in Indonesia are under increasing pressure from illegal fishing and other unsustainable activities, but this stress could potentially be reduced by mariculture that is planned and managed to minimize ecological and social impacts. It must be emphasized, however, that capability and suitability analyses represent only an initial step in a broader marine spatial planning framework that supports the development of sustainable forms of mariculture. These marine spatial planning tools only address strategic questions related to the potential location of mariculture facilities. Site capability and suitability analyses cannot address operational issues related to specific farm-level activities which can impose significant environmental impacts (such as effluent handling, disease control, seed and feed sources). These tools also cannot resolve carrying capacity issues related to the appropriate size or number of farms located within areas deemed suitable for development. Resolution of these questions must take place within a broader planning framework and requires detailed follow-up studies plus ongoing monitoring and enforcement of environmental regulations to ensure that environmental quality is protected and social or cultural impacts do not emerge as a result of mariculture development.

\section{References}

Aswani, S. \& Hamilton, R. (2004) 'Integrating Indigenous Ecological Knowledge and Customary Sea Tenure with Marine Science and Social Science for Conservation of Bumphead Parrotfish (Bolbometopon muricatum) in the Roviana Lagoon, Solomon Islands', Environmental Conservation, Vol. 31, No. 1, pp. 69-83.

Baldacchino, G. (2006) 'Islands: Objects of Representation: Editorial Introduction', Geografiska Annaler, Vol. 87B, No. 4, pp. 247-251.

Bolstad, P. (2005) GIS Fundamental: A First Text on Geographic Information Systems (2nd edition), White Bear Lake MN, Eider Press.

BTNKW (2003) Database Taman Nasional Kepulauan Wakatobi, Bau-Bau, Buton, Balai Taman Nasional Kelautan Wakatobi (BTNKW). 
Buitrago, J., Rada, M., Hernandez, H. \& Buitrago, E. (2005) 'A Single Use Site Selection Technique, using GIS, for Aquaculture Planning: Choosing Locations for Mangrove Oyster Raft Culture in Margarita Island, Venezuela', Environmental Management, Vol. 35, No. 5, pp. 544-556.

Caffrey, J.M., Chapin, T., Jannasch, H.W. \& Haskins J.C. (2007) 'High Nutrient Pulses, Tidal Mixing and Biological Response in a Small California Estuary: Variability in Nutrient Concentrations from Decadal to Hourly Time Scales,' Estuarine, Coastal and Shelf Science, Vol. 71, Nos. 3-4, pp. 368-380.

Caine, G.D., Truscott, J., Reid, S. \& Ricker, K. (1987) Biophysical Criteria for Siting Salmon Farms in British Columbia, Victoria BC, Ministry of Agriculture and Fisheries.

Chou, R. \& Lee, H.B. (1997) Commercial Marine Fish Farming in Singapore. Aquaculture Research, Vol. 28, No. 10, pp. 767-776.

COREMAP (2001) Baseline Study of Sulawesi Tenggara, Jakarta, Coral Reef Rehabilitation and Management Program and LIPI.

Cross, S.F. \& Kingzett, B.C. (1992) Biophysical Criteria for Shellfish Culture in British Columbia: A Site Capability Evaluation System, Victoria BC, Ministry of Agriculture, Fisheries and Food.

FAO (1989) Site Selection Criteria for Marine Finfish Netcage Culture in Asia, Rome, Food and Agricultural Organization.

Hamilton, R. \& Walter, R. (1999) 'Indigenous Ecological Knowledge and its Role in Fisheries Research Design: A Case Study from Roviana Lagoon, Western Province, Solomon Islands', SPC Traditional Marine Resource Management and Knowledge Information Bulletin, Vol. 11, pp. 13-25.

Henderson, A.R. \& Davies, I.M. (2000) 'Review of Aquaculture, its Regulation and Monitoring in Scotland', Journal of Applied Ichthyology, Vol. 16, No. 2, pp. 200-208.

Interlandi, S.J. \& Crockett, C.S. (2003) 'Recent Water Quality Trends in the Schuylkill River, Pennsylvania, USA: A Preliminary Assessment of the Relative Influences of Climate, River Discharge and Suburban Development', Water Research, Vol. 37, No. 8, pp. 1737-1748.

Jackson, R.E. (2004) 'Offshore Islands in Australia and New Zealand: Questions of tourism and conservation management'. Islands of the World VIII: Changing Islands Changing Worlds. Proceedings Vol. 1, November, Kinmen Island, Taiwan, pp. 353-377.

Johannes, R.E. (1982) 'Traditional Conservation Methods and Protected Marine Areas in Oceania', Ambio, Vol. 11, No 5, pp. 258-261. 
Kapetsky, J.M. \& Aguilar-Manjarrez, J. (2007) Geographic Information Systems, Remote Sensing and Mapping for the Development and Management of Marine Aquaculture. Rome, Food and Agricultural Organization.

Karthik, M., Suri, J., Saharan, N. \& Biradar, R.S. (2005) 'Brackishwater Aquaculture Site Selection in Palghar Taluk, Thane District of Maharashtra, India, using the Techniques of Remote Sensing and Geographical Information System', Aquaculture Engineering, Vol. 32, No. 2, pp. 285-302.

Kile, N., Parks J.E., Wilson A.M. \& Lam, M. (2000) Solomon Islands Community Participation in Marine Conservation Areas: Integrating Science and Custom. Paper presented at the 9th International Coral Reef Symposium, Bali, Indonesia, October.

Kokkranikal, J., McLellan, R., \& Baum, T. (2003) 'Island Tourism and Sustainability: A Case Study of the Laksahweep Islands', Journal of Sustainable Tourism, Vol. 11, No. 5, pp. 426-447.

Kryvi, H. (1995) 'Aquaculture in Norway: The Use of Areas; Conflicting Interests' in H. Reinertsen \& H. Haaland (eds.) Sustainable Fish Farming: Vol. 1, Rotterdam, Netherlands, A.A. Balkema, pp. 195-199.

McLeod, I., Pintus, F. \& Preston, N. (2002) 'The Use of Geographical Information System for Land-Based Aquaculture Planning', Aquaculture Research, Vol. 33, No. 2, pp. 241250 .

Nath, S.S., Bolte, J.P., Ross, L.G. \& Aquilar-Manjarrez, J. (2000) 'Application of Geographical Information Systems (GIS) for Spatial Decision Support in Aquaculture', Aquaculture Engineering, Vol. 23, Nos. 1-3, pp. 233-278.

Nurdjana, M.L. (2006) Indonesian Aquaculture Development. Paper presented at the RCA International Workshop on Innovative Technologies for Eco-Friendly Fish Farm Management and Production of Safe Aquaculture Food, Bali.

Papoutsoglou, S.E. (2000) 'Monitoring and Regulation of Marine Aquaculture in Greece: Licensing Regulatory Control and Monitoring Guidelines and Procedures', Journal of Applied Ichthyology, Vol. 16, Nos. 4-5, pp. 167-171.

Perez, O.M., Telfer, T.C. \& Ross L.G. (2003) 'Use of GIS-based Models for Integrating and Developing Marine Fish Cages within the Tourism Industry in Tenerife, Canary Islands', Coastal Management, Vol. 31, No. 4, pp. 355-366.

Perez, O.M., Telfer, T.C. \& Ross, L.G. (2005) 'Geographical Information Systems-Based Models for Offshore Floating Marine Fish Cage Aquaculture Site Selection in Tenerife, Canary Islands', Aquaculture Research, Vol. 36, No. 10, pp. 946-961.

Pet-Suede, L. (2003) Mariculture as A Sustainable Livelihood Strategy in Support of Conservation and Management: A Case Study of Komodo National Park, Indonesia, Bangkok, Network of Aquaculture Centres in Asia-Pacific (NACA). 
Rajitha, K., Mukerjee, C.K. \& Chandran, R.V. (2007) 'Application of Remote Sensing and GIS for Sustainable Management of Shrimp Culture in India', Aquacultural Engineering, Vol. 36, No. 1, pp. 1-17.

Rimmer, M.A., McBride S. \& Williams, K.C. (2004) Advances in Grouper Aquaculture, Canberra, ACIAR.

Ross, L.G., Mendoza, A.Q.M. \& Beveridge, C. (1993) 'The Application of Geographical Information Systems to Site Selection for Coastal Aquaculture: An Example based on Salmonid Cage Culture', Aquaculture, Vol. 112, Nos. 2-3, pp. 165-178.

Salam, M.A., Khatun, N. \& Ali, M. (2005) 'Carp Farming Potential in Barhatta Upazilla, Bangladesh: A GIS Methodological Perspective', Aquaculture, Vol. 245, Nos. 1-4, pp. 7587.

Smith, J.F. \& Kreutzberger, W.A. (1987) 'Water Quality’, Science, Vol. 237, No. 4810, p. 11 .

Tookwinas, S. (1989) 'Review of Knowledge on Grouper Aquaculture in South East Asia', Advances in Tropical Aquaculture, Vol. 9, No. 4, pp. 429-435.

Walters, B.B. (2007) 'Competing Use of Marine Space in a Modernizing Fishery: Salmon Farming meets Lobster Fishing in the Bay of Fundy', The Canadian Geographer, Vol. 51, No. 2, pp. 139-159.

Williams, N. \& Baines, G. (1993) 'Partnerships in Tradition and Science' in N. Williams \& G. Baines (eds.) Traditional Ecological Knowledge: Wisdom for Sustainable Development, Canberra, Australian National University, Centre for Resource and Environmental Studies, pp. 1-12.

Williams, I., Williams, K.C., Smith, D.M. \& Jones, M. (2006) 'Polka-dot grouper, Cromileptes altivelis, can utilize dietary fat efficiently', Aquaculture Nutrition, Vol. 12, No. 5, pp. 379-387.

Yamamoto, K. (2006) Asia Pacific Marine Finfish Aquaculture Network (APMFAN) and the Efforts towards Sustainable Grouper Aquaculture in the Region. Paper presented at NACA/ FAO Regional Workshop on Future of Mariculture: A Regional Approach for Responsible Development of Marine Farming in the Asia-Pacific Region, China. 